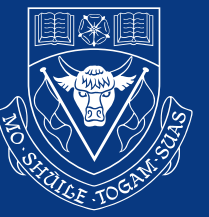

UNIVERSITY OF CALGARY

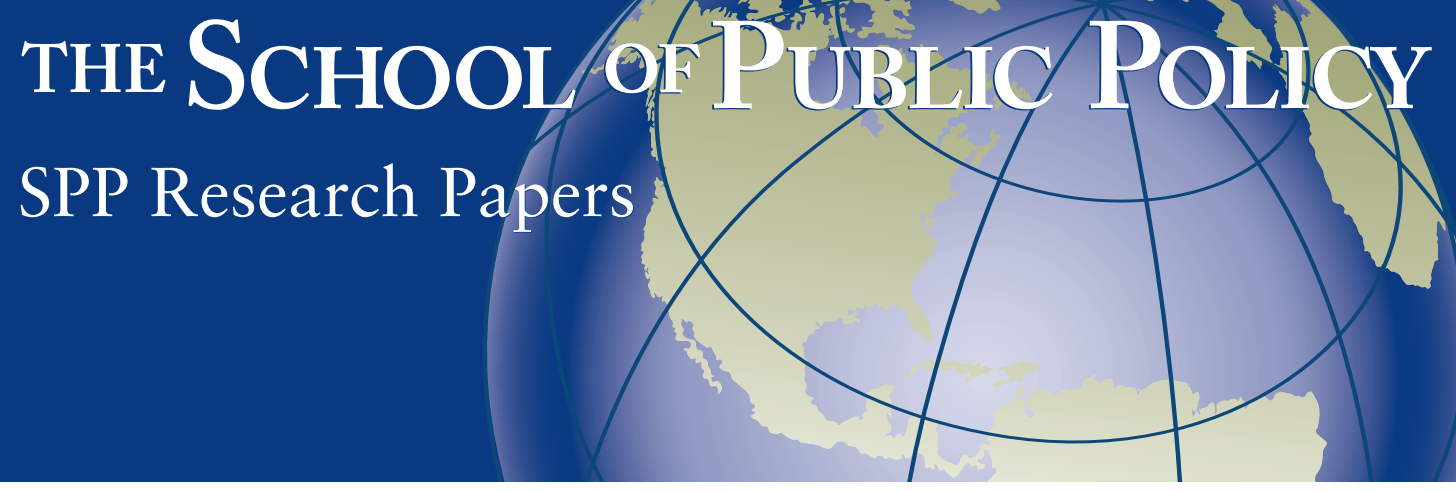

Volume 5•Issue 21・June 2012

\title{
HOW YOU PAY DETERMINES WHAT YOU GET: ALTERNATIVE FINANCING OPTIONS AS A DETERMINANT OF PUBLICLY FUNDED HEALTH CARE IN CANADA*
}

Ronald Kneebone

The School of Public Policy, University of Calgary

\section{SUMMARY}

A Canadian returning home from a visit to a physician has no idea of the cost of providing the service just received. This is true for two reasons. One is because he or she does not receive a bill to pay. The other reason has to do the myriad of ways provincial governments fund the provision of health care. Health care is financed by a wide variety of types of taxation, by intergovernmental transfers determined by opaque and changing rules, by borrowing against future taxes and by drawing down savings. Confusion over how health care is funded creates a fiscal illusion that it is cheaper than it really is; a fiscal illusion that grows larger the less provincial governments rely on taxing individuals. In this paper it is shown that when provincial health spending is financed in ways other than taxation, it grows two to three times more quickly than it would have otherwise. From 2001-2008 alone, these distortions amounted to $\$ 6.75$ billion at the national level, draining funds from other government services many of which have been shown to keep Canadians healthier and so reduce their demand for health care. Simply put, when Canadians are clear about the true cost of health care they more effectively play the traditional role of consumers by guarding against waste and inefficiency and so contribute to a more efficient and effective publicly-funded health care system.

\footnotetext{
* I owe thanks to Oksana Grynishak for excellent research assistance and also owe thanks to Herb Emery and two anonymous referees for helpful suggestions. I remain responsible for any errors and omissions.
} 


\section{INTRODUCTION}

Different levels of government - federal, provincial, municipal - often argue over which should pay for what public service. A perennial argument in Canada, for example, is over which level of government should pay what share of publicly funded health care. Provincial governments have the constitutional responsibility to provide publicly funded health care, but they regularly and vigorously demand that the federal government contribute to its financing. For its part, the federal government seems anxious to be seen to contribute to a government service that is highly valued by voters.

This must seem a strange debate for taxpayers. At the end of the day they know it all comes back to them. They are the one and only taxpayer that all levels of government draw upon and so it is they who pay for publicly funded health care. Given that they are the one and only taxpayer, Canadians may wonder why levels of government argue over which of them should be responsible for raising revenues. If it costs a billion dollars to provide a service, what does it matter which level of government collects that billion dollars from Canadians?

It matters. As Canadians listen to arguments between politicians over which level of government ought to be taxing them, they need to be aware that how, and how much of, their tax dollars are spent depends on those arrangements. Negotiations between the federal and provincial governments over which should be paying for health care are not esoteric debates to be ignored. How, and how much, of their tax dollars are spent also depend on whether provincial governments use revenues gained through taxation, from borrowing, or from returns on investments. All of this matters because these sources of revenue differ with respect to the extent to which they subject government to the ire of taxpayers.

These beliefs are what lie behind proposals that economists often make to impose greater discipline on government spending decisions by making clear the link between spending and taxation. These beliefs have been bolstered by empirical results suggesting that financing spending indirectly - with the use of borrowing and intergovernmental transfers - creates a fiscal illusion in the minds of taxpayers that they are somehow receiving government-provided benefits at zero or low cost.

In this report I examine the issue of how government expenditures depend on the source of the revenue paying for that spending. I do so in the context of health-care spending and financing in Canada. In the next section I provided some background on publicly funded health care in Canada and provide some measures of how sensitive health spending is to age, income and other influences. I then turn to a discussion of the concept of fiscal illusion; the idea that taxpayers underestimate the true cost of publicly provided goods and services because of the myriad of ways in which it is financed. Next, I provide empirical evidence on the question of whether fiscal illusion plays a role in determining the level of publicly funded health care in Canada. Finally, I turn to the question of how important these considerations are, and assess the extent to which alternative arrangements might improve the health-care value Canadians receive for their tax dollars. 


\section{BACKGROUND}

What are the sources of growth in health-care spending? The answer to this question is of importance to governments tasked with funding the provision of health care. In Canada, health care is a responsibility of provincial governments. The concern of those governments is that this expenditure obligation is outstripping their capabilities for financing it. Part of this concern is based on the experience of the recent past and part has to do with the potential for growth in this spending responsibility in the future.

Figure 1 presents data showing why provincial governments are worried about the long-term outlook for health-care spending; health spending is eating up a large and growing fraction of their revenues. The figure reports (for each of three time periods, for each province and for Canada as a whole) the average fraction of total provincial revenues expended on health care. ${ }^{l}$ The three time periods define three distinct periods of government finances in Canada.

\section{FIGURE 1: PROVINCIAL HEALTH-CARE EXPENDITURES AS A FRACTION OF REVENUES}

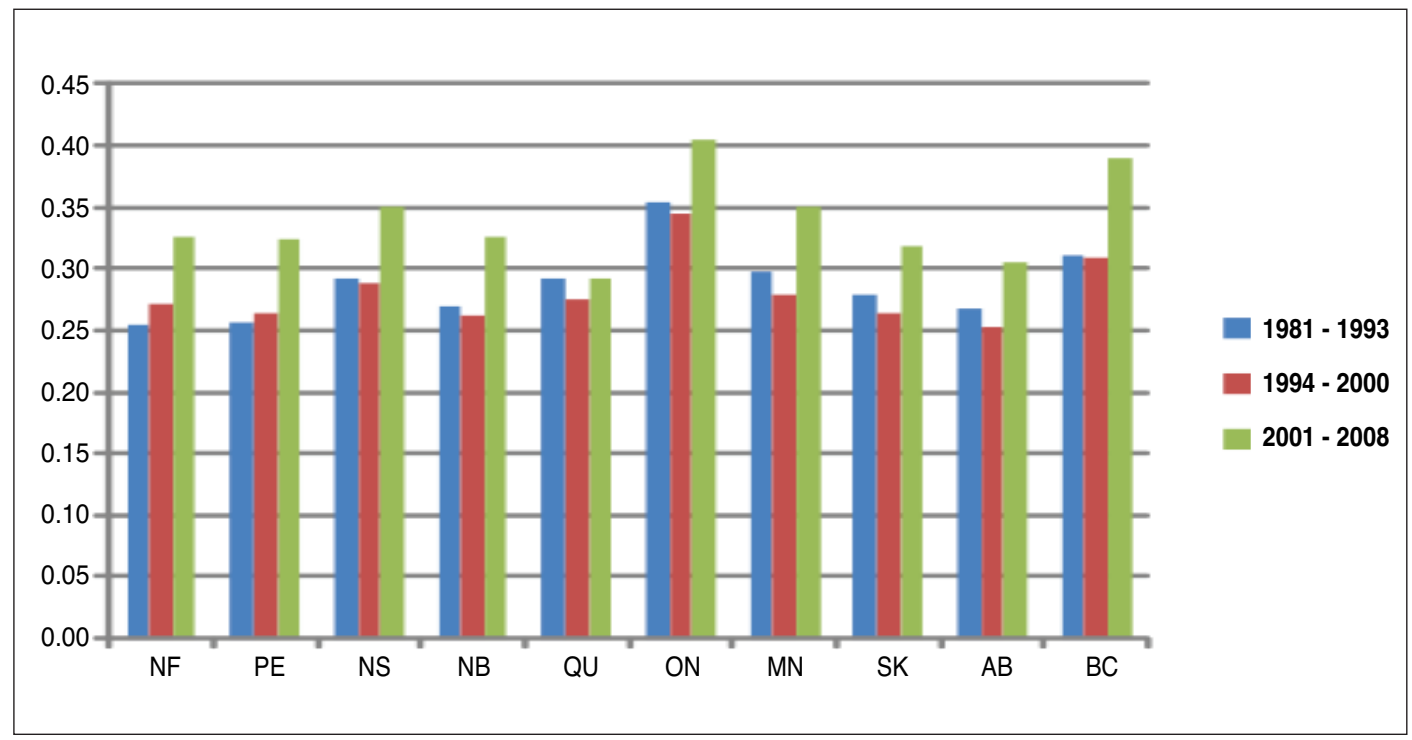

The period 1981-1993 identifies a period of turmoil for government budget makers. Two recessions (1982-83 and 1991-92) contributed to large budgetary deficits, a situation made worse by the failure of governments to reign in deficits during the intervening period of strong economic growth. ${ }^{2}$ The result was a rapid accumulation of debt - particularly, but not solely, by the federal government.

l Total revenue includes provincial own-source revenue - tax dollars provincial governments raised by taxing citizens of their province - plus the revenue transferred to the provinces from the federal government. The latter are tax dollars raised by the federal government by taxing all Canadians.

2 For a detailed discussion see Ronald Kneebone and Jennifer Chung, "Where Did the Debt Come From?" in Christopher Ragan and William Watson (editors) Is the Debt War Over?, Institute for Research on Public Policy, Montreal, 2004. 
By the mid-1990s the need to eliminate deficits and reduce debt was apparent. A sense of urgency to address the problem was aided by a credit rating downgrade of federal government debt in 1993. ${ }^{3}$ In response to a perceived need to eliminate deficits and reduce debt, the period 1994-2000 was marked by concerted efforts to control spending. This included efforts to reduce publicly funded health-care expenditures, which in most provinces (Newfoundland \& Labrador and Prince Edward Island being the exceptions) resulted in a small decline in the fraction of total provincial government revenues consumed by health spending.

The final period, 2001-2008, ends just prior to the onset of the financial crisis that precipitated the most recent recession in Canada. It was a period of more or less steady economic growth and was a largely expansionary period for government spending. This was, as Figure 1 shows, particularly so for health-care spending, which grew at a significantly faster rate than total provincial revenues in every province.

Figure 2 looks at provincial government spending on health care relative to spending on other provincial government programs, each measured in real per-capita dollars and presented as an index relative to their 1981 values. ${ }^{4}$ Whereas provincial governments have managed to restrain non-health-related program spending since the early 1990s the same cannot be said of healthcare spending. The effort to control health spending in the mid-1990s was made in conjunction with efforts to control other program spending as well. As Figure 2 shows, however, while the halt of growth of other program spending introduced in the mid 1990s has proved to be more or less permanent, the control of health-care spending proved to be rather short-lived.

FIGURE 2: HEALTH VS. OTHER PROGRAM SPENDING

(REAL PER-CAPITA DOLLARS, 1981=1.0)

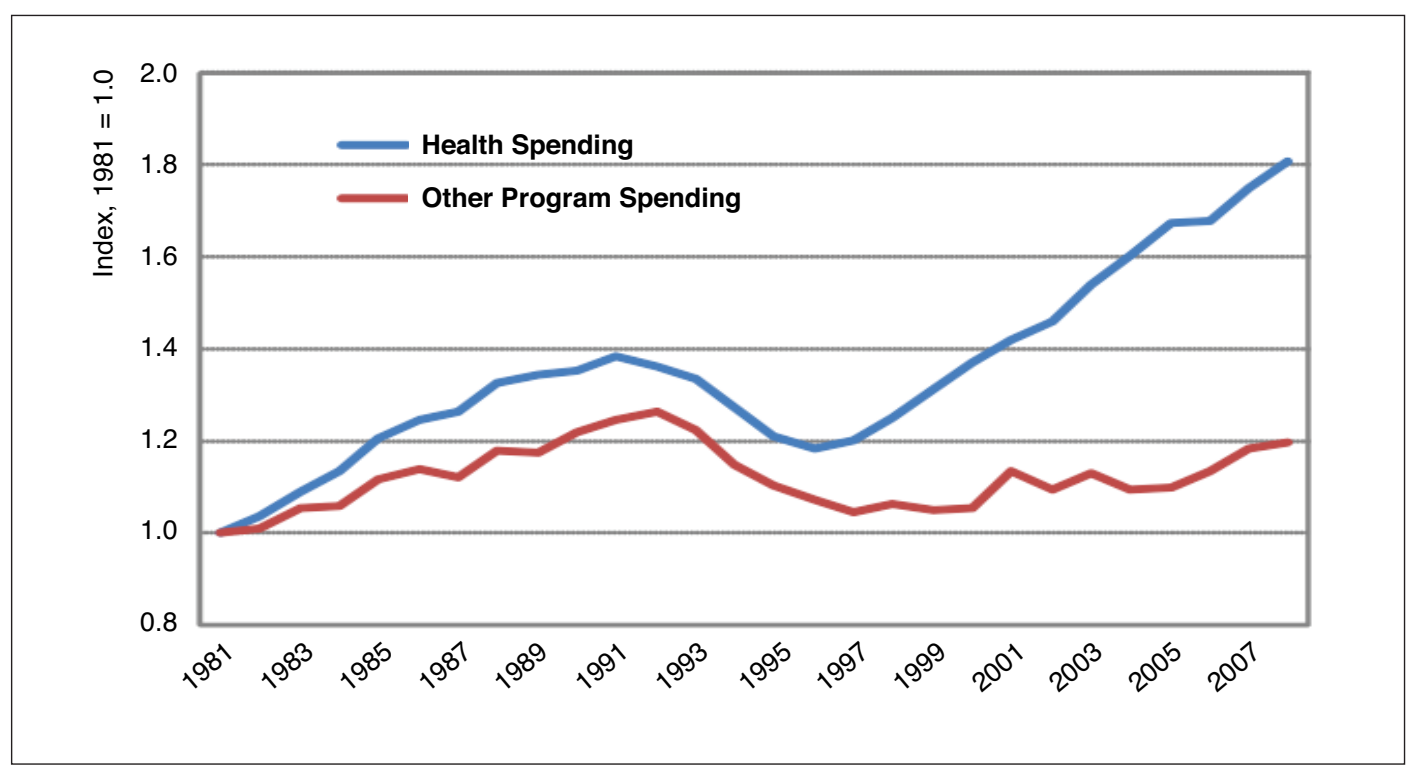

3 A similar downgrade of US government debt in August 2011 recently caused politicians in that country to at least begin to confront the serious fiscal situation of their governments.

4 Data is the total for 10 provinces. Provincial program spending defined as total current expenditure less current transfers to other levels of government and interest on public debt. Source: CANSIM Table 3840004. Health spending is from the CIHI database. Both series are measured in real per-capita dollar values. Nominal values are deflated using the government current expenditure implicit price index from CANSIM Table 3840036. 
Figures 1 and 2 tell us about how the growth in health-care spending has changed relative to provincial revenues and relative to other categories of program spending, but do not tell us what has been the driving force behind health-care spending. Understanding this is important for gaining insights into what may be the rate of growth in health-care spending in the future. It is concern over the potential for this future growth that will be driving funding negotiations between provincial governments and the federal government.

Governments have recently adopted a simple approach for gaining some insight into the implications for their budgets of the likely path of health-care spending into the future. The approach involves assuming that population ageing and GDP - the collective income of Canadians - are key drivers of health-care spending. Removing these influences from data measuring health-care spending isolates the amount of health-care spending that is the result of other considerations. These other considerations are said to contribute to excess cost growth or, using a more neutral term, residual cost growth.

The approach, introduced by the US Congressional Budget Office ${ }^{5}$ and adopted for use by the Parliamentary Budget Officer ${ }^{6}$ in Canada defines;

$H C P_{t}=H C P_{t-1}\left(\frac{G D P P_{t}}{G D P P_{t-1}}\right)^{e}\left(\frac{A G E_{t}}{A G E_{t-1}}\right)\left(1+x_{t}\right)$

Where $H C P$ is publicly financed health-care spending per capita, GDPP is provincial gross domestic product per capita, $A G E$ is per-capita health expenditure due to ageing, and $x$ is the residual cost growth factor. In their application of this approach, the $\mathrm{CBO}$ and the $\mathrm{PBO}$ assume a value of one for the income elasticity of health-care spending $(e=1){ }^{7}$ With data on $H C P$, $G D P P$ and $A G E$, the rate of growth in per-capita health-care spending due to factors other than ageing and income (that is, the value of $x$ ) is determined residually. ${ }^{8}$

Along with assumptions about GDP growth, the elasticity of health spending with respect to GDP growth and assumptions about demographic change, the calculations described in equation (1) can be used to suggest what health-care expenditures might look like in the future. The PBO projects that provincial health-care costs will increase from 6.8 percent of GDP in 2007 , to 10.9 percent in 2050 , and to 12.3 percent by 2085 .

5 “The Long-Term Outlook for Health Care Spending," Congressional Budget Office, Congress of the United States, November 2007.

6 See Appendix B of “Fiscal Sustainability Report," Parliamentary Budget Office, February 18, 2010. http://www.parl.gc.ca/PBO-DPB/documents/FSR_2010.pdf

7 This means they assume that a one-percentage point increase in GDPP results in a one-percentage point increase in age-adjusted health-care spending per capita. There is some controversy in the literature over the size of the income elasticity. See, for example, Livio Di Matteo, "The Income Elasticity of Health Care Spending," European Journal of Health Economics, Volume 4, pp. 20-29, 2003. I return to this issue below.

8 The Canadian Institute for Health Information (CIHI) provides data describing provincial government-funded healthcare spending per capita (the $H C P$ variable) and by age group from 1981 to 2008 . These data enable us to account for the change in health spending resulting from changes in the age distribution in each province. It enables us, in other words, to measure the $A G E$ variable. The GDPP variable is readily available using provincial values of GDP and population accessible from the Statistics Canada CANSIM database. 
Instead of projecting ahead, I use (1) to allocate the growth of per-capita health-care spending during the period 1982-2008 as being due to ageing, income growth, and the residual factor. My purpose in doing so is to gain a better understanding of what has been the driver of healthcare spending in the past.

Figure 3 shows calculations using data describing the average level of health-care spending, population and GDP for all provinces. It represents, then, an average for Canada. The figure shows the change in per-capita spending on publicly funded health care since 1981, measured in real (2009) dollars. Following the CBO and PBO, it assumes an income elasticity of unity.

\section{FIGURE 3: PROVINCIAL HEALTH-CARE SPENDING DRIVERS}

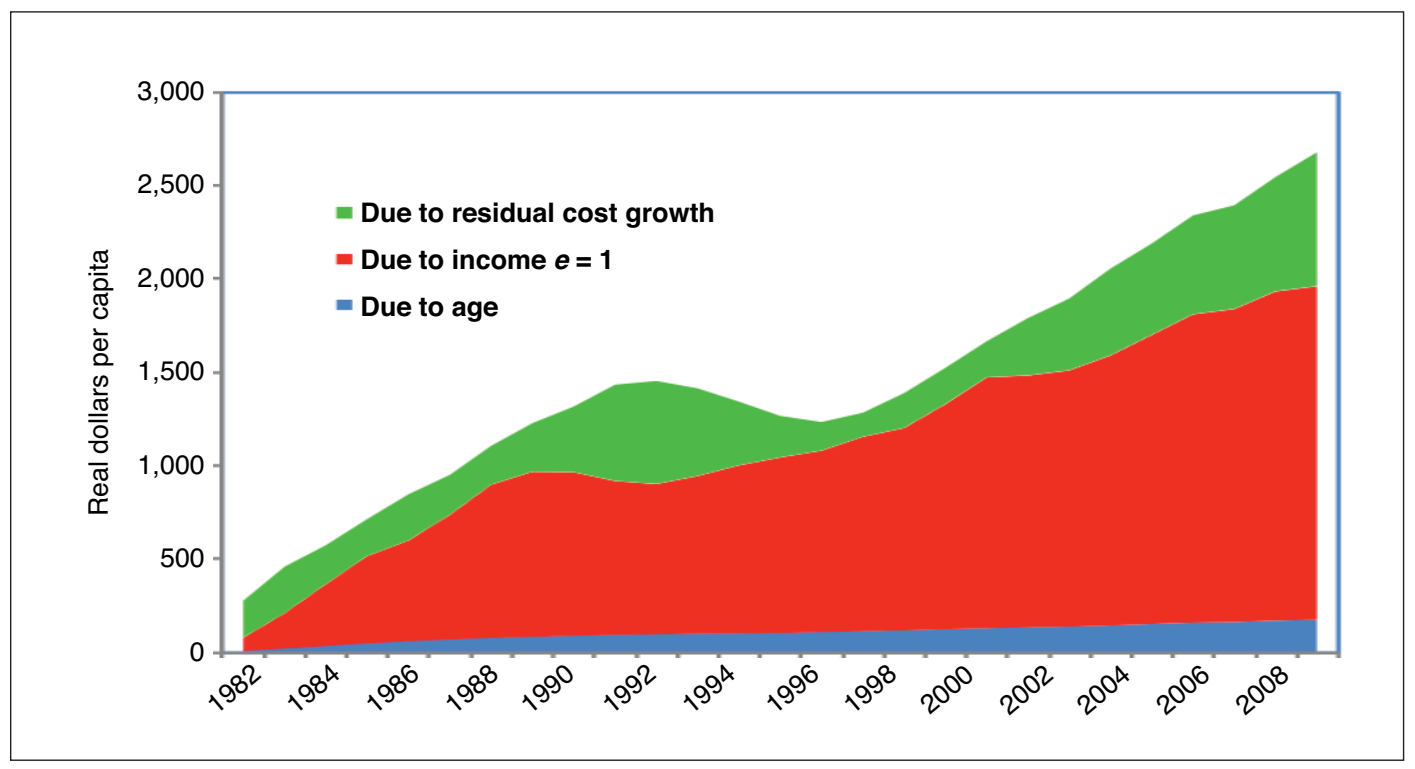

The calculations presented in the figure show that ageing played a relatively small role in the growth of per-capita spending over this period. The largest driver of health-care costs was income with residual cost growth making a smaller but more volatile contribution.

The calculations need to be interpreted cautiously because the allocation of health-care costs between what is income-driven and what is residual cost growth rests on the assumption one makes about the income elasticity of publicly funded health-care costs. The assumption used to produce Figure 3, that the income elasticity is unity, results in the majority of growth in healthcare spending being due to the growth in per-capita income (the red area) but with a significant amount of growth nonetheless being due to the residual growth factor (the green area). Assuming a smaller value of the income elasticity would allocate more of the explanation for total spending growth to the residual factor and less to income.

We define as age-adjusted health-care expenditure $(A H E)$ that spending due to factors other than ageing. In Figure 3 the change in AHE since 1981 is the sum of the red and green areas; the growth in spending not explained by the change in the age-profile of the population (the blue area). $A H E$, then, is explained by changes in per-capita income plus potential explanations for residual cost growth. 
What is particularly important to note from Figure 3 is that whatever the assumption made about the income elasticity, fluctuations in age-adjusted publicly financed health-care expenditures $(A H E)$ are mainly due to fluctuations in residual cost growth. This is seen more easily in Figure 4, which presents the same information as Figure 3 but in terms of annual changes.

\section{FIGURE 4: ANNUAL CONTRIBUTIONS TO PROVINCIAL HEALTH SPENDING}

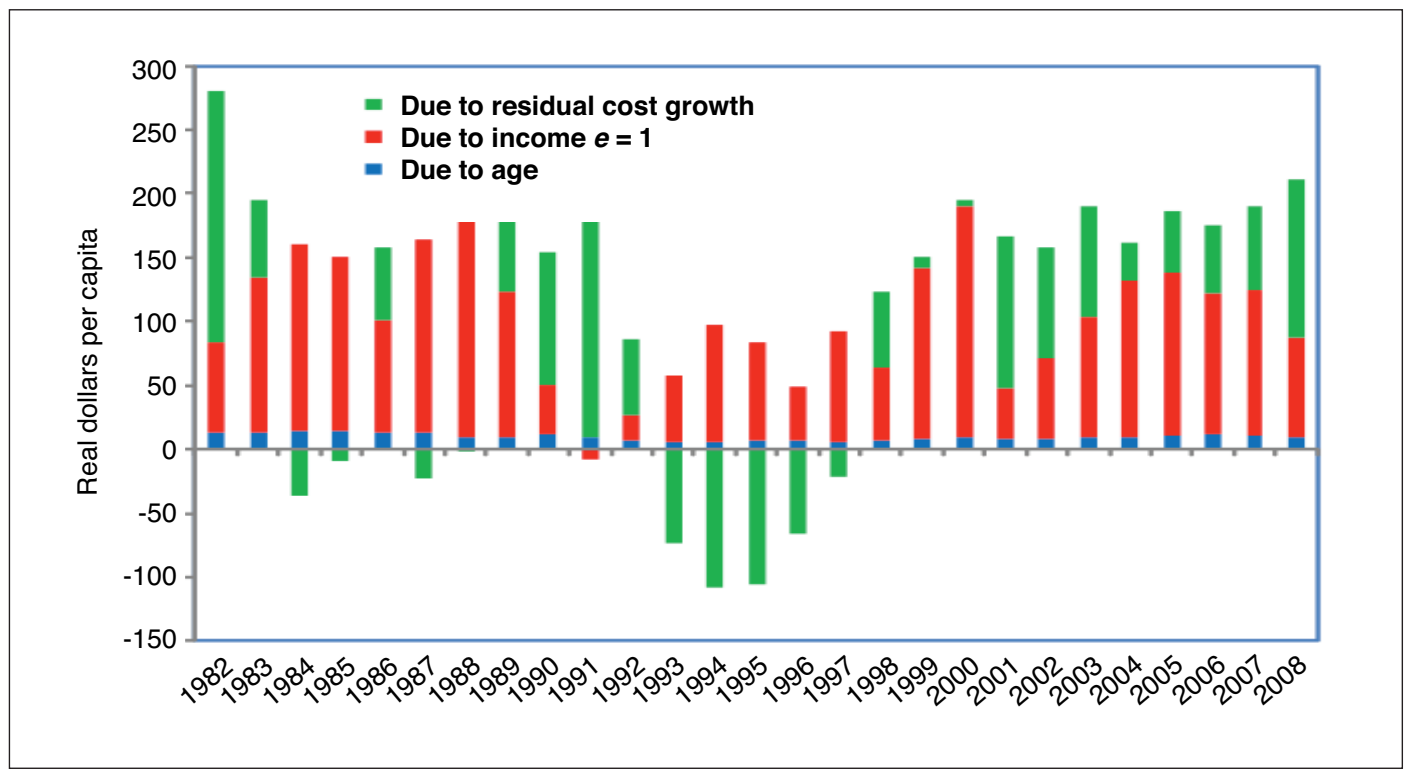

In Figure 4 a reduction in health spending for reasons other than ageing and income occurred in the mid-1990s. Indeed, this occurred despite growing per-capita incomes that were contributing to increases in spending (the red bars). This suggests there are important influences other than ageing and income that drive health-care expenditures and that these influences are not "trendy," in the sense of adding to health spending more or less steadily over time. Also evident in Figure 4 is the large increase in health spending for reasons other than income growth and ageing after 2000. 


\section{FIGURE 5: PROVINCES}
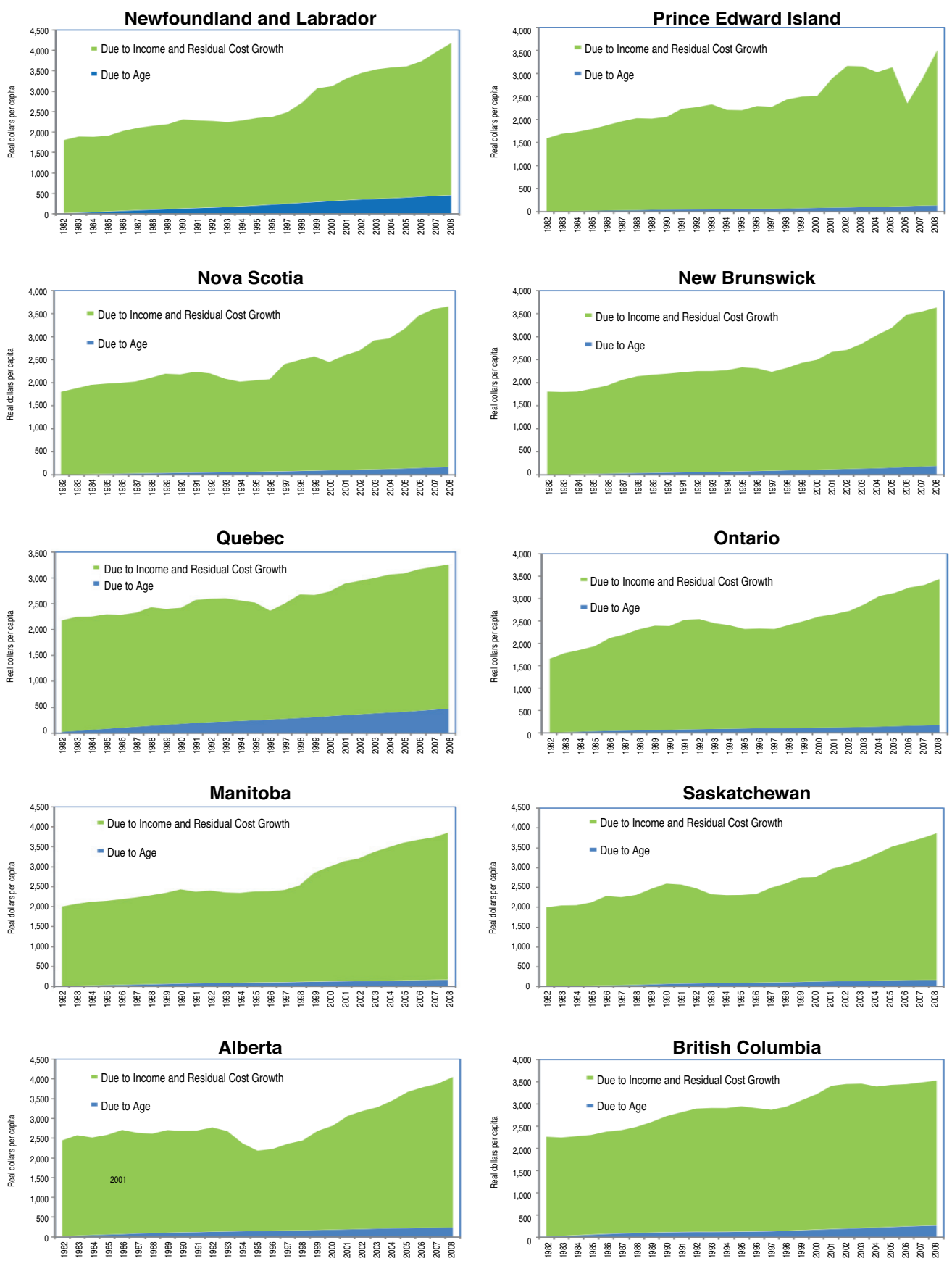

Figure 5 (above) shows similar calculations to those in Figure 3 but does so for each province. Here I separate the change in total provincial health-care spending since 1981 into only two parts; that due to the changing age profile of the population (blue area) and that due to the combined influences of income and residual cost growth (green area). The reason for not identifying the separate contributions to growth in health spending of income and residual cost growth is because of greater uncertainty over the income elasticity of health spending at the provincial level. Greater uncertainty arises because in Canada most provincial governments 
receive transfers intended to equalize their spending capacities. This means that the sensitivity of provincial health-care expenditures may have a smaller relationship to provincial income than otherwise. For example, consider a country composed of two equal size regions. Suppose an idiosyncratic shock results in region A enjoying a four percent rate of GDP growth while region B suffers zero percent growth. Since the regions are equal sized, national GDP growth is two percent. With full equalization of fiscal capacity, an income elasticity of unity at the national level results in a growth rate of health-care expenditure equal to two percent nationally and in each region. The measured income elasticity in region; A is 0.5 while that in region $\mathrm{B}$ is zero. The greater is the fiscal interdependence of regions the lower is the regional income elasticity of income.

The graphs in Figure 5 show some significant differences across provinces with respect to the growth in provincial health spending since 1981. Part of these differences is due to ageing which has played a considerably larger role in Quebec and Newfoundland \& Labrador than elsewhere. The pattern of growth in Ontario is, not surprisingly given Ontario's size, similar to that for Canada as a whole (Figure 3), but other provinces differ considerably from the average for Canada. Alberta, for example, introduced very large per-capita cuts to real spending on health in the mid-1990s as part of an effort to eliminate the provincial deficit. A number of other provinces introduced cuts during this same period though they were not as large as those in Alberta. Following those deep cuts in the mid-1990s, Alberta introduced rapid and continuous growth in health spending. Indeed, all provinces, following a moderation of spending in the mid-1990s, introduced rapid spending increases throughout the late 1990s and 2000s.

I conclude this section by emphasizing the following observation. As illustrated in Figure 4, fluctuations in age-adjusted health-care spending are due mainly to fluctuations in the residual factor. This is also apparent from the fluctuations in provincial health spending shown in Figure 5. These fluctuations in age-related health care spending are at times much too severe to be explained by changes in per-capita income, a variable that changes relatively slowly and actually falls in value only in the deepest of recessions. If fluctuations in age-adjusted healthcare spending are due mainly to fluctuations in the residual factor, then this leaves open an important question: what determines fluctuations in the residual growth factor?

It is to that question I turn next. In the following section I present a model describing the determinants of growth in the demand for publicly funded health care. The goal of the model is to determine empirically the importance of how publicly funded health-care spending is financed for determining the pattern of change in the residual growth factor of health-care spending. ${ }^{9}$

\footnotetext{
It is possible to apply the approach described in equation (1) to sub-categories of provincial health-care spending for which age-specific data is available. The PBO does this and shows that the roles of aging, income and residual cost growth differ by health spending category. It shows, for example, that growth in drug costs is more sensitive to the age and the residual factors than is the growth in spending on physicians. I do not pursue this issue in what follows though it would be a useful extension to learn whether the way in which health care is financed influences certain health-care spending categories more than others.
} 


\section{METHODS OF FINANCING AND THE GROWTH IN PUBLICLY FUNDED HEALTH-CARE COSTS}

The goal in this section is to use observations on past health-care spending patterns to uncover whether it is possible to identify the impact that government funding choices may have had on that spending. My approach is to assume publicly funded health-care costs are determined by demographics, price inflation and the demands of voters. My key assumption, then, is that voters determine the amount of health-care spending by provincial governments and that their votes are sensitive to their desire (demand) for health care and to their income and the price they must pay to receive that care.

To begin, I remove the influence of inflation from the analysis by adjusting expenditure data by a price index showing the rate of inflation in current government expenditures. ${ }^{10}$ I remove the effects of population growth on health-care expenditures by measuring expenditure data on a per-capita basis. Finally, I remove the influence of changes in the age distribution of the population as described earlier. After these adjustments, the variable of interest is defined as age-adjusted, real per-capita provincial government spending on publicly funded health care. I will identify this variable as AHE. All of these adjustments can be done for each province using province-specific data and can be done for the period 1981-2008. Thus there are 280 data points on $A H E, 28$ observations for each of 10 provinces.

My hypothesis is that $A H E$ is determined by the demand for publicly financed health spending by a median voter. The median voter is that hypothetical person with a preference for health spending which is greater than that preferred by half the population and less than that preferred by the other half of the population. Under majority rule voting, the preference of the median voter determines the level of publicly financed health-care spending. Demand is specified as being a function of the income of the median voter and the price for publicly financed health care that the median voter perceives he or she pays.

In the literature the income of the median voter is often measured using real per-capita GDP. That measure is somewhat problematic in provinces with large corporate sectors or in provinces dependent on export-driven growth. In such provinces movements in GDP may not be a reasonable measure of movements in the income of the median voter. To avoid this problem, rather than use GDP per capita I measure the income of the median voter by median family-earned income. ${ }^{11}$

More challenging is developing measures of the price that the median voter is perceived to pay for publicly funded health care. Developing the price measure is challenging because publicly funded health care is not financed with an earmarked tax from which the revenue can be spent only on health care. Instead, publicly funded health care - and indeed all government spending programs - is financed from many sources of revenue that are often extracted from taxpayers only indirectly. Thus provincial governments extract revenue from taxpayers directly

\footnotetext{
10 Source: CANSIM data base, Table 3840036.

11 Statistics Canada CANSIM database, Table 2020203. No measure is without its problems. Median family income may not account for the distribution of voters across income levels being different from families. See Phillip Nelson, "Redistribution and the Income of the Median Voter," Public Choice, Vol. 98, 1999 for discussion.
} 
via income taxes, less directly via sales taxes, and less directly again via the revenue they receive from the federal government in the form of intergovernmental transfers. ${ }^{12}$ The modern system of taxation, with its myriad of tax types, exemptions and transfers, therefore makes it challenging for voters to understand exactly how much they are contributing to the cost of providing publicly financed health care. Some sources of revenue make this more challenging than others. In this way it is believed that the way in which revenue is raised can influence a person's perception of the cost of government programs. ${ }^{13}$

Political economists have coined the term fiscal illusion to describe the tendency for taxpayers to systematically underestimate the true cost of publicly provided goods and services because of the difficulty they have in understanding how much they pay in taxes toward specific programs. Generally speaking, fiscal illusion arises when there is a gap between government expenditures and the amount of taxes paid by voters. This funding gap must be filled by revenue sources other than taxation of voters. There are, therefore, three sources of fiscal illusion in the government's budget; ${ }^{14}$

- Intergovernmental transfers;

- Investment income; and

- Deficits.

Each of these components of the provincial budget can be understood to play a role in contributing to fiscal illusion, and so determining the price provincial voters are perceived to pay for provincial government spending, including publicly funded health services. Let's consider each in turn.

12 Economists also note that the incidence of these revenues - who actually pays the tax as opposed to who is legislated to pay it - is typically opaque and so further complicates the voter's efforts to assess his or her true share of program costs.

13 This issue is not unique to Canada or to publicly financed single-payer systems of health-care provision. Current research in the US is focused on ensuring health-care consumers are aware of the real costs of health care so that they are able to evaluate whether the benefits they are receiving exceed the costs. See, for example, Katherine Baicker and Dana Goldman ("Patient Cost-Sharing and Healthcare Spending Growth," Journal of Economic Perspectives, Volume 25, No. 2, Spring 2011) who note that the dramatic growth in health-care spending in the US coincides with an equally dramatic change in the way health-care spending is financed; a change that has seen outof-pocket financing of health care fall from over 50 percent prior to 1965 to under 15 percent in 2008 .

14 Other sources of fiscal illusion identified in the literature include the complexity of the tax system, the sensitivity of tax revenue to income, and renter illusion. Renter illusion refers to the observation that local jurisdictions with larger numbers of renters tend to have higher levels of government spending. The suggestion is that because renters pay property taxes only indirectly (the owner of the rental accommodation pays the property tax directly with the tenant paying it only indirectly via his or her rent), they underestimate the true cost of publicly provided goods and services. The more sensitive tax revenue is to income, the more easily government gains revenue without the need to incur the wrath of voters by increasing tax rates. Thus more income-sensitive tax systems make it appear to voters that increases in government spending are being enjoyed without an increase in taxes. When tax revenue is less sensitive to income, additional revenue is often available only via increases in tax rates; increases that draw the ire of taxpayers and so make spending increases more difficult. Finally, the complexity of the tax system - different deductions and tax rates for people with different income, age and even personal characteristics combined with a myriad of different types of taxes paid in different ways (via payroll deductions versus direct payments at the cash register, etc) - is believed to cause taxpayers to underestimate their tax bills and so underestimate the true cost of public provision of goods and services. In the empirical approach utilized in this paper I assume that the complexity of the tax system, its sensitivity to income and the share of the population living in rental accommodations has not changed appreciably over the time period of my analysis (1981-2008) or has changed at a more or less constant rate. To the extent differences in these measures vary by province, I capture their influence with a fixed effects specification in the empirical model. 


\section{Intergovernmental Transfers}

Federal transfer payments to provincial governments reduce the price that taxpayers perceive they pay for health care because the tax revenues funding the transfers are collected from taxpayers across Canada. Provincial government spending therefore appears to be cheaper to provincial taxpayers since others are covering some fraction of the cost. Federal transfers, then, are said to induce a fiscal illusion that provincial spending is less costly to the provincial taxpayer than otherwise. The price of provincial spending appears lower than it would be had the provincial government raised provincial tax rates to fund the spending program.

Figure 6 presents data on all federal grants to each of the provincial governments as well as a Canadian average. I present averages for each of three periods, each period defining a different federal policy with respect to transfer payments.

\section{FIGURE 6: TOTAL FEDERAL TRANSFERS TO PROVINCES}

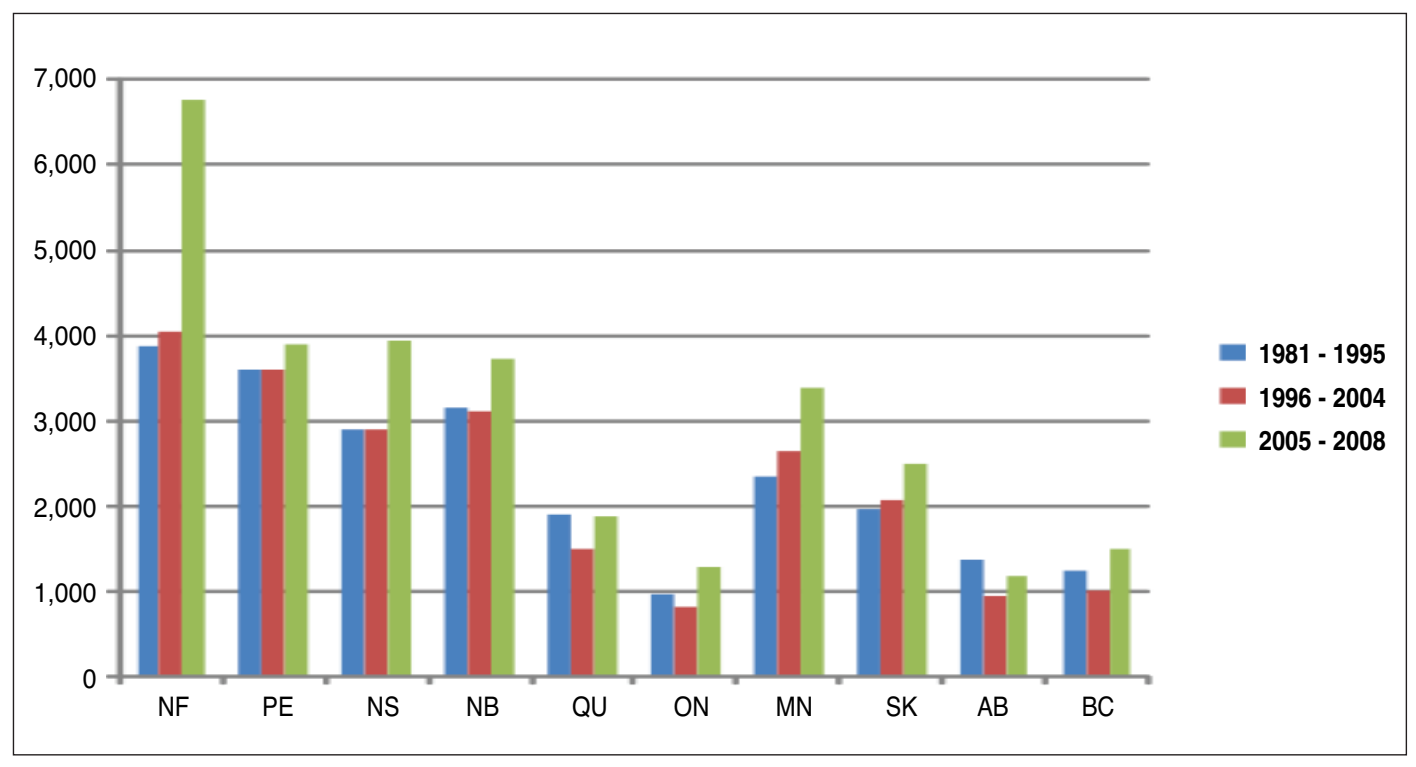

The period 1981-1995 saw the federal government attempt to restrain the growth in the size of transfers it was making to provincial governments. Federal deficits were large and the federal government was trying to control the growth in its expenditures. In an effort to do so, the federal government introduce a number of limits on the growth rate of transfers during this period. $^{15}$

The federal credit downgrade in 1993 made it clear that more was needed to reduce the federal deficit. In 1995 the introduction of the new Canada Health and Social Transfer (CHST) was accompanied by a reduction in the size of federal transfers. ${ }^{16}$ These changes were larger for some provinces than others and resulted in reductions in the size of real per-capita transfers in a number of provinces during the period 1996 to 2004.

\footnotetext{
${ }^{15}$ For a useful summary, see Department of Finance, A History of Health and Social Transfers, http://www.fin.gc.ca/fedprov/his-eng.asp, December 2011.

16 The CHST has since been divided into two separate transfers: the Canada Health Transfer (CHT) and the Canada Social Transfer (CST).
} 
The return to budget surplus at the federal level and a prolonged period of economic growth after 2004 made it feasible for renewed growth in federal transfers. This was marked particularly by the signing of the 10-Year Plan to Strengthen Health Care in late 2004. As Figure 6 shows, the additional $\$ 41.3$ billion of federal transfers that accompanied the 10-year plan had a dramatic effect on real per-capita federal transfers in all provinces. ${ }^{17}$

The literature suggests a positive relationship between the size of federal transfers and the size of provincial program expenditures, including age-adjusted health-care spending $(A H E)$, in part because taxpayer-voters do not directly observe these transfers and so underestimate the price of provincial expenditures. Stanley Winer describes the problem in this way:

It is often argued that separation of public spending and taxing decisions engenders in the voter overoptimistic hopes that someone else will bear the cost of public services, thereby inducing an increase in the size of government. ${ }^{18}$

Funding public expenditures with intergovernmental transfers also make it unclear which level of government is responsible for spending outcomes. Thus Erik Wibbels notes that;

As subnational governments are financed by intergovernmental transfers from taxes raised at other levels of government, the difficulty of assigning responsibility for policy mounts. With complex formulas for matching grants, opaque rules governing discretionary transfers, and policy a function of intricate intergovernmental negotiation and contestation, voters seem prone to take informational shortcuts... Under such conditions, national and subnational governments compete in a game of credit-claiming for popular initiatives and burden-shifting for costly or unpopular programs. Confused by these conflicting claims and complex intergovernmental finances, citizens have a hard time correctly attributing responsibility for publicsector outcomes... ${ }^{19}$

For reasons like these provincial governments are sometimes described as behaving as though they are spending fifty-cent dollars because their own voters are not paying the full cost of services. The magnitude of the fiscal illusion caused by intergovernmental transfers is identified by the sensitivity of provincial spending to changes in transfers relative to the sensitivity of spending to increases in the incomes of taxpayers. We return to this issue when we discuss the results of the empirical exercise.

\footnotetext{
17 The particularly large real per-capita increase in Newfoundland and Labrador also reflects the Offshore Accord signed with the federal government in 2005.

18 "Some Evidence on the Effect of the Separation of Spending and Taxing Decisions," Journal of Political Economy, Volume 91, No. 1, 1983.

19 "Madison in Baghdad? Decentralization and Federalism in Comparative Politics," Annual Review of Political Science, Volume 9, No. 1, 2006), page 170.
} 


\section{Investment Income}

Provincial revenues obtained by way of investment income are mainly in the form of natural resource royalties but also include the return on financial assets. These revenues are obtained without the need to raise taxes on voters. Instead, government realizes these revenues via royalty regimes that give them a share of the revenues earned on the sale of minerals extracted by corporations and by earning rates of return on financial assets. As a consequence, these revenues potentially add to the fiscal illusion of the median voter that provincial spending is being enjoyed without an increase in his or her tax burden.

It is worth considering the possibility that investment income may impose a different level of fiscal illusion than federal transfers. Whereas federal transfers exert a fiscal illusion because they provide revenue to provincial governments that is collected from taxpayers living in other provinces, investment income may do so because it provides revenue from future generations of provincial taxpayers. In Alberta, for example, the spending of energy royalty income represents consumption of natural resource capital that would otherwise generate benefits to future generations of Albertans. Put more directly, there is no doubt that Albertans understand that energy royalty income is contributing to lower taxes.

Data on real per-capita investment income paid to provincial governments identifies the usual suspects as enjoying high levels of such income: Alberta, Saskatchewan and BC and, more recently, Newfoundland and Labrador. These data also highlight the volatility in this income. Thus, real per-capita investment income received by the government of Newfoundland and Labrador increased by over 3.5 times between 1998 and 2008 as a result of strong oil prices and an expansion of offshore oil field developments. Over the same period, these revenues approximately doubled in both Alberta and Saskatchewan, reflecting strong oil prices in Alberta and strong oil and potash prices in Saskatchewan. It is noteworthy that the fastest rates of growth in $A H E$ over the period 1998-2008 were in Alberta (an average of 4.95 percent per year) and Newfoundland \& Labrador (4.36 percent per year). Again, however, there were other confounding influences that may have played a role in the growth of health-care spending that our empirical approach will need to account for.

\section{Deficit}

The remaining source of difference between what provincial governments spend on programs and what they require voters to pay in taxes is what those governments finance with borrowing; what is referred to as the government's deficit. The choice between financing a public expenditure with taxes as opposed to borrowing is a potential source of fiscal illusion. The argument is that individuals are more likely to accurately perceive the cost of publicly provided goods and services if they pay for them through current taxation, as opposed to the deferred taxation that results from current borrowing. Using deficits rather than taxes to fund public expenditures may, therefore, result in an underestimate of the cost of those expenditures and encourage a higher level of spending.

The anticipated effect of an increase in the deficit on spending is ambiguous and dependent on whether provincial taxpayers behave in a way that economists describe as Ricardian. Ricardian taxpayers identify an increase in the deficit as equivalent to a tax increase and hence a reduction in income. That is, the borrowing that accompanies a deficit incurs a debt that, at 
some point, must be repaid by imposing taxes. Since the present value of the two tax bills is the same, funding health care with current taxation is perceived by the taxpayer as being exactly equivalent as funding it with borrowing; they both reduce consumption possibilities by the same amount. If taxpayers behave in this way there is no fiscal illusion arising from the choice of borrowing as opposed to taxation. In this case, an increase in the size of the government's budget deficit will influence spending by the same amount as an increase in taxes. That is, an increase in the deficit will be associated with lower spending on health care.

There is considerable controversy over whether taxpayers behave in ways economists identify as Ricardian. If, for example, the span of time between borrowing and repayment is long enough, those citizens subject to current taxation may be different from those subject to future taxation. In that case the cost of programs funded by borrowing will appear smaller to the current generation than the cost of programs funded through taxation. In this case, larger deficits will reduce the perceived price of government expenditures for the current generation of voters, and we will expect deficits to be associated with higher spending. ${ }^{20}$

\section{FIGURE 7: REAL PER-CAPITA PROVINCIAL DEFICIT}

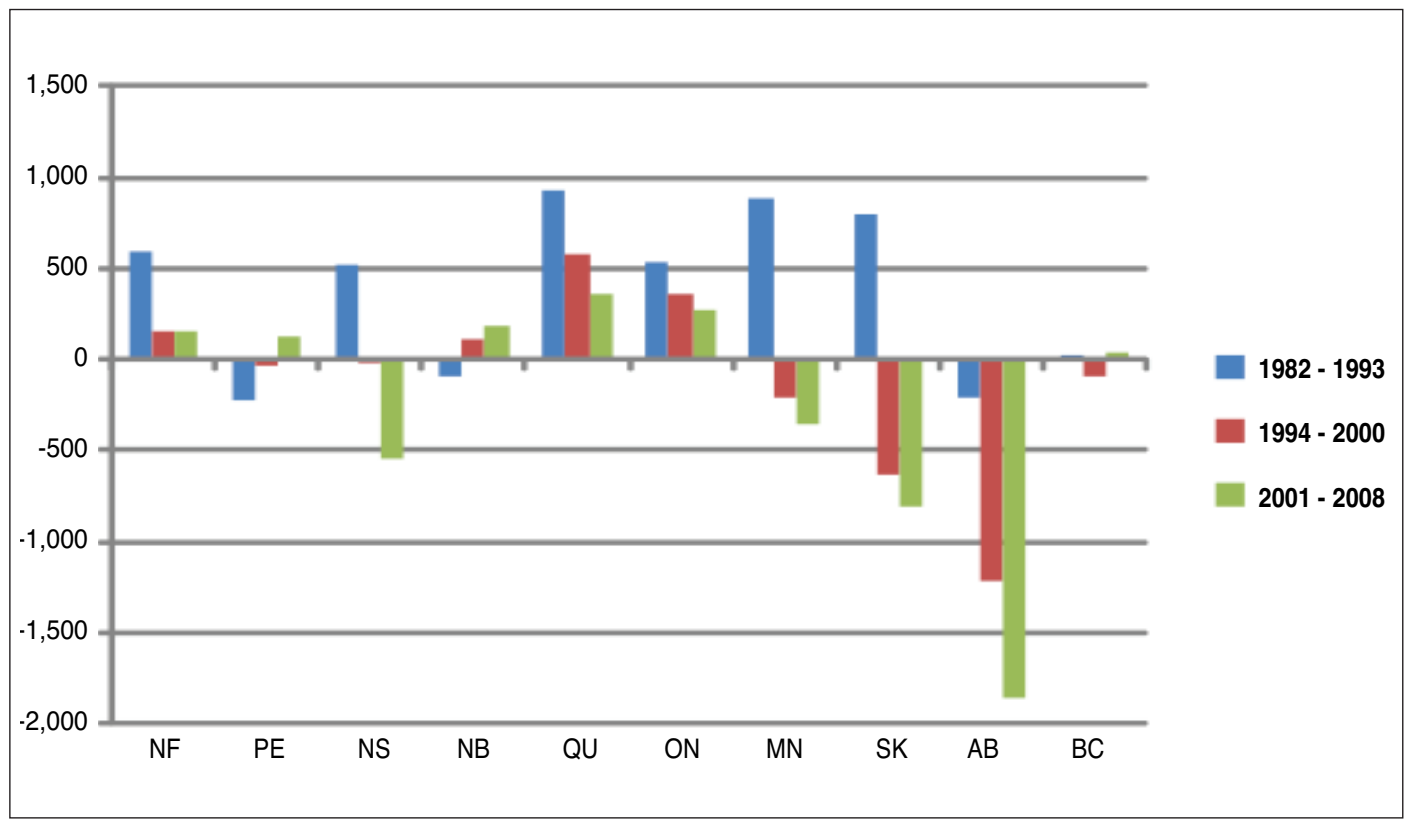

${ }^{20}$ The debate over the appropriateness of the Ricardian assumption is due to Robert Barro. An assessable discussion of issue appears in "The Ricardian Approach to Budget Deficits," Journal of Economic Perspectives, Volume 3, No. 2, Spring 1989). Barro suggests that parents increase their savings and the size of bequests to their children to compensate them for borrowing they (the parents) vote for. In this way the consumption possibilities of current taxpayers are reduced when government spending increases, regardless of how far into the future the debt repayment may occur. This rescue of the Ricardian assumption rests on important assumptions about the extent to which taxpayers are liquidity constrained (i.e., able to borrow against expected future income) and other considerations. The Ricardian hypothesis remains an open question in economics. 
Figure 7 presents data on the average size of the provincial deficits (measured in 2009 percapita dollars) during three time periods: 1982-1993, 1994-2000 and 2001-2008. The period 1982-1993 was one of high deficits in six of the 10 provinces. This was followed by a period of fiscal retrenchment during which provincial governments reduced their deficits and, in the case of Manitoba and Saskatchewan, turned them into sizable surpluses. Finally, the period 2001-2008, which ended just as the most recent recession hit in earnest, was one of generally strong economic growth that allowed all provinces to reduce deficits and/or expand surpluses. This was particularly true of the energy-producing provinces. With the exception of New Brunswick, the average deficit over the period grew smaller. If voters do not behave in ways economists describe as Ricardian, this pattern of deficit reduction suggests a gradual increase in the perceived price of publicly funded health care.

\section{AN EMPIRICAL TEST}

In this section I examine the roles of each of the considerations described above in determining the levels of real per-capita age-adjusted provincial health-care expenditures $(A H E)$ over the period 1981-2008. The method for doing so is to employ multiple regression on data describing $A H E$ and the variables discussed and defined in the previous section.

I assume a simple linear relationship between these variables; ${ }^{21}$

$$
\begin{aligned}
\text { AHE }_{i, t}=\alpha_{i} & +\alpha_{1}{ }^{* \text { Transfers }_{i, t}}+\alpha_{2} * \text { Deficit }_{i, t}+\alpha_{3} \text { Investment Income }_{i, t}+\alpha_{4} * \text { Median Income }_{i, t} \\
& +\alpha_{5} * A H E_{i, t-1}+\alpha_{6} * \text { Trend }_{t}+\varepsilon_{i, t}
\end{aligned}
$$

In this representation, the $i$ subscript identifies a province $(i=\mathrm{BC}$, Alberta, ....) while the $t$ subscript denotes a time period $(t=1981, \ldots, 2008)$. Included in this specification is the term $\alpha_{i}$, which identifies a province-specific intercept term meant to measure the influence on $A H E$ of any province-specific characteristics not captured by the other terms on the right-hand side of the equation. ${ }^{22}$ The lagged value of $A H E$ is included on the assumption that there is persistence in provincial health spending and a linear trend is included to try to capture the influence of changes in technology on health-care expenditures. ${ }^{23}$

\footnotetext{
${ }^{21}$ For a similar approach see Rosella Levaggi and Roberto Zanola, "Flypaper Effect and Sluggishness: Evidence from Regional Health Expenditure in Italy," International Tax and Public Finance, Volume 10, 2003, pp 535-47.

22 These fixed effects may include political and institutional factors, which differ across provinces. The organization of health care into regional health authorities, for example, may be more prevalent in some provinces than in others and this may have an impact on $A H E$.

${ }^{23}$ A time trend will capture the effect of any influence on health spending that grows more or less constantly, including the public's expectation for new spending. As noted earlier, the time trend may also measure the influence of provincial differences in tax complexity, renter illusion and the sensitivity of tax systems to income.
} 
An important statistical issue that arises when using time series data (as here) is the potential for identifying a spurious correlation between $A H E$ and the right-hand side variables. This problem arises when variables are said to be non-stationary. Analysts test for this possibility with what are known as unit root tests. Tests show that each of our variables is non-stationary in levels, but that first differencing these data causes them to be stationary. ${ }^{24}$ Avoiding spurious correlations therefore requires that we first difference the data. The result is that the model becomes:

$$
\begin{aligned}
\Delta A H E_{i, t}=\alpha_{0} & +\alpha_{1} * \Delta \text { Transfers }_{i, t}+\alpha_{2} * \Delta \text { Deficit }_{i, t}+\alpha_{3} * \Delta \text { Investment Income } e_{i, t} \\
& +\alpha_{4} * \Delta \text { Median Income } e_{i, t}+\alpha_{5} * \Delta A H E_{i, t-1}+e_{i, t}
\end{aligned}
$$

where the symbol " $\Delta$ " denotes a first difference. Thus, $\Delta A H E_{i, t}=A H E_{i, t}-A H E_{i, t-1}$ and similarly for the other variables. ${ }^{25}$ The results of estimating the model as represented by equation (3) are provided below. ${ }^{26}$

$$
\begin{aligned}
& \Delta A H E_{i, t}=24.666+0.051 * \Delta \text { Transfers }_{i, t}+0.0317 * \Delta \text { Deficit }_{i, t}+0.026 * \Delta \text { Investment Income }_{i, t} \\
& (5.095) *(0.011)^{*} \quad(0.008) * \quad(0.010)^{*} \\
& +0.004 * \Delta \text { Median } \text { Income }_{i, t}+0.344 * \Delta A H E_{i, t-1}+e_{i, t} \\
& (0.001)^{*} \quad(0.049)^{*}
\end{aligned}
$$

$\operatorname{Adj} \mathrm{R}^{2}=0.237 \quad \mathrm{~N}=250$

All variables have a statistically significant influence on $A H E$. Since all variables are measured in dollar terms, the coefficients of this regression offer a straightforward interpretation.

The positive coefficient on Median Income indicates that as the family income of the median voter increases, the demand for publicly funded health care grows and governments expand spending accordingly. The size of the estimated coefficients indicates that a $\$ 1$ increase in median family income (Median Income) results in a \$0.004 increase in real per-capita ageadjusted provincial spending on publicly funded health care $(A H E)$. Put another way, since the average family size in Canada in 2009 was 2.9 persons, then a $\$ 1$ increase in per-capita income results in an increase in age-adjusted provincial health spending of $\$ 0.011$ per capita. Similarly, the coefficient on Transfers indicates that a $\$ 1$ increase in per-capita federal transfers to provincial governments results in a $\$ 0.051$ increase in per capita $A H E$.

\footnotetext{
24 Testing was done using the EViews statistical package. EViews enables one to perform panel unit root tests that allow for individual intercept and linear trend terms in the tests and for selection of the number of lagged difference terms. Test results are available on request.

25 Note that the fixed effects term disappears due to first differencing and the linear trend becomes a constant term.

${ }^{26}$ Absolute values of standard errors appear in brackets. A standard error identified with an asterisk denotes a coefficient that is statistically different from zero at the five percent level or better. The regression allowed for crosssection heteroskedasticity and contemporaneous correlation of error terms.
} 
The relative magnitudes of the coefficients on median income and federal transfers is interesting because it provides evidence on what economists have come to refer to as the flypaper effect; the oft-observed evidence that a government finds it easier to expand spending when receiving a transfer from another level of government than when receiving tax dollars from citizens. ${ }^{27}$ The evidence from our regression shows that in Canada, over the period 19822008 , a $\$ 1$ increase in per-capita income (equivalent to an increase in family income of \$2.90) has on average and across provinces been associated with a $\$ 0.011$ per-capita increase in ageadjusted provincial health spending. A $\$ 1$ per-capita transfer from the federal government, if treated as equivalent to a lump sum increase in taxpayer income, ought then to cause the median voter to favour a $\$ 0.011$ increase in age-adjusted provincial health spending. What we find instead is that provincial governments have tended to increase age-adjusted health-care spending by nearly five times that amount; by $\$ 0.051$.

A $\$ 1$ increases in a provincial government deficit is found to result in a $\$ 0.032$ increase in publicly funded age-adjusted spending. The positive sign indicates voters do not vote on health-care provision in the way economists believe they would were they behaving as socalled Ricardians. The coefficient is, rather, consistent with the interpretation that deficits reduce the price that voters perceive they pay for publicly funded health care.

In a similar way the coefficient on Investment Income suggests that revenue realized from royalty payments and the return on savings funds causes voters to underestimate the price they believe they are paying for health care.

The constant term in the regression measures the influence on publicly funded age-adjusted health-care spending of considerations that change at a more or less constant rate over time. Possible influences include changes in the complexity of the tax system, creating a fiscal illusion encouraging increases in spending; increases in health technologies leading to demands for greater health spending; and the public's growing expectations for new public insurance coverage. The coefficient indicates that due to factors that change at a constant rate over time, age-adjusted per-capita spending on publicly funded health care increased by $\$ 24.67$ per year. Over the period of analysis, 1981-2008, age-adjusted per-capita spending on publicly funded health care increased by an average of $\$ 58.00$ per year. Thus these slowly changing influences account for just over 40 percent of the observed increase in health spending.

\section{THE IMPLICATIONS}

How important is it that provincial government spending on health care responds differently depending on whether it is financed out of federal transfers, deficits, and investment income than from taxation of voters' incomes? The importance depends on the combination of two things; the sensitivity of health spending to the mode of financing and on the size of these sources of income. In the previous section I provided measures of how sensitive health spending is to the mode of financing. Prior to that, I provided information on the size and fluctuations of provincial revenues available from federal transfers, investment income and their deficits. It is now time to put these two considerations together.

\footnotetext{
${ }^{27}$ For an accessible discussion of the flypaper effect see James Hines and Richard Thaler, "Anomalies: The Flypaper Effect," Journal of Economic Perspectives, Volume 9, No. 4, pp. 217-226, 1995. The authors suggest that the flypaper effect arises because, upon receipt of an intergovernmental transfer, the choices to the public are not framed as between additional spending or lower taxes but, rather, over how the new revenue ought to be spent.
} 
I consider two time periods, each defining a tumultuous time for provincial government finances. During the period 1989-1998, provincial governments dealt with generally increasing federal transfers in the early part and dramatic cuts in the latter part. They also dealt with rising deficits in the early period and realized significant cuts in the size of their deficits in the latter half. The period 2001-2008 was a period of consistent growth in federal transfers, whereas deficits increased or decreased depending on the province.

Table 1 identifies the additional spending on health care that is predicted to have been expended in each province as a result of receiving revenue via federal grants, investment income and provincial borrowing (deficit), and spending those revenues differently than revenues received via taxing provincial voters. Thus for the period 1989-1998, total provincial health-care spending over those 10 years was $\$ 1.16$ billion higher than it would have been, had provincial governments during that period spent all health dollars as they would have had all revenue come from taxing the current generation of voters in their province. Put differently, had all provinces during this period been required to fund health care solely by taxing their own citizens, health-care spending would have been $\$ 1.16$ billion less during those 10 years. Over the eight-year period from 2001-2008, provincial health-care spending is predicted to have been $\$ 6.75$ billion higher than it would have been had provinces during the period relied solely on taxing current voters in their province.

TABLE 1: FINANCE-INDUCED SPENDING (MILLIONS OF 2009 DOLLARS)

\begin{tabular}{|c|c|c|c|c|c|c|c|c|c|c|c|}
\hline & NL & PE & NS & NB & QU & ON & MN & SK & $A B$ & BC & Canada \\
\hline \multicolumn{12}{|c|}{$1989-1998$} \\
\hline DEFICIT & 0 & 22 & 33 & 115 & 1,062 & 2,597 & -51 & -296 & -164 & 388 & 3,706 \\
\hline INVEST & -9 & 2 & 1 & 72 & -8 & -64 & 53 & 8 & -397 & 396 & 55 \\
\hline GRANT & -51 & -12 & -20 & -80 & -773 & -451 & -1 & 128 & -590 & -753 & $-2,602$ \\
\hline Total & -60 & 13 & 15 & 107 & 281 & 2,082 & 1 & -160 & $-1,152$ & 31 & 1,158 \\
\hline \multicolumn{12}{|c|}{ 2001-2008 } \\
\hline DEFICIT & 14 & 2 & -90 & -3 & 767 & 1,060 & 11 & 68 & 451 & 328 & 2,608 \\
\hline INVEST & 7 & -4 & -21 & -24 & 314 & 27 & -62 & 31 & 210 & -362 & 116 \\
\hline GRANT & 141 & 4 & 213 & 111 & 392 & 1,923 & 275 & 97 & 262 & 609 & 4,026 \\
\hline Total & 162 & 2 & 102 & 84 & 1,473 & 3,010 & 224 & 196 & 922 & 575 & 6,750 \\
\hline
\end{tabular}

As the table shows, these period averages hide the fact that the different sources of revenue have sometimes had opposing influences on spending, and that some provinces have had quite different experiences than others. During the period 1989-1998, for example, generally large provincial deficits, particularly in Ontario and Quebec, are predicted to have encouraged an extra $\$ 3.7$ billion of health-care spending, whereas the large cuts to federal grants during the period are predicted to have caused health-care spending to have fallen by $\$ 2.6$ billion. The average for the period also hides important differences across provinces. For example, during 1989-1998 spending on health care in Alberta was \$1.15 billion less than it would have been had that province not suffered a loss of federal transfers, a reduction in investment income, and 
had the provincial government not been cutting its deficit. Thus although the net effect on spending across all provinces ( $\$ 1.16$ billion) over this period was relatively small, this was only because of the offsetting influences of grants and deficits in some provinces, and the fact those income sources moved in different directions in some provinces than others.

The net effect on provincial health spending of these influences ( $\$ 6.75$ billion) was much higher during the period 2001-2008, because the influence of deficits and grants on health spending moved in the same direction. Provincial deficits continued to result in higher healthcare spending than otherwise (by $\$ 2.6$ billion) while federal grants, increasing rapidly during this period, encouraged an additional $\$ 4.0$ billion of health spending above what would have occurred had provinces been forced to rely solely on their own tax revenues.

As this discussion suggests, the figures reported in Table 1 depend not only on how sensitive health spending is to different sources of revenue, but also on how volatile those sources of revenue are. For example, revenue received in the form of grants contributes to volatility in health spending, not only because the sensitivity of health spending to that source of revenue is nearly five times greater than the sensitivity to changes in median income, but also because transfers are much more volatile than median income.

Table 2 (below) provides evidence of the relative volatility of federal transfers, deficits, investment income and median income for the period 2001 to 2008. The mean rate of growth of real per-capita transfers outpaced the rate of growth in median family income in all provinces except PEI, Saskatchewan and Alberta. In all provinces the volatility of transfers, investment income and provincial deficits - as measured by the difference in minimum and maximum annual rates of growth - greatly exceeded that of median family income. Choosing to fund health-care expenditures from these sources therefore invites volatility into health-care budgets. 
TABLE 2: AVERAGE ANNUAL RATES OF GROWTH; 2001-2008

\begin{tabular}{|c|c|c|c|c|c|}
\hline & & Median Income & Federal Grants & Provincial Deficit & Investment Income \\
\hline & Max & $7.0 \%$ & $192.9 \%$ & $122.7 \%$ & $94.9 \%$ \\
\hline \multirow[t]{3}{*}{ NF } & Min & $-4.2 \%$ & $-58.5 \%$ & $-355.8 \%$ & $-41.0 \%$ \\
\hline & Mean & $3.2 \%$ & $8.8 \%$ & $-219.7 \%$ & $8.8 \%$ \\
\hline & Max & $14.9 \%$ & $30.8 \%$ & $-7.6 \%$ & $15.0 \%$ \\
\hline \multirow[t]{3}{*}{ PE } & Min & $-5.4 \%$ & $-33.0 \%$ & $-680.9 \%$ & $-28.8 \%$ \\
\hline & Mean & $4.5 \%$ & $1.3 \%$ & $-199.4 \%$ & $-5.0 \%$ \\
\hline & Max & $5.6 \%$ & $81.8 \%$ & - & $1.2 \%$ \\
\hline \multirow[t]{3}{*}{ NS } & Min & $-2.8 \%$ & $-28.7 \%$ & - & $-16.5 \%$ \\
\hline & Mean & $1.5 \%$ & $3.5 \%$ & $13.9 \%$ & $-6.2 \%$ \\
\hline & Max & $3.9 \%$ & $31.7 \%$ & $2311.9 \%$ & $2.8 \%$ \\
\hline \multirow[t]{3}{*}{ NB } & Min & $-3.8 \%$ & $-12.3 \%$ & $-1686.9 \%$ & $-10.0 \%$ \\
\hline & Mean & $1.4 \%$ & $1.9 \%$ & $-262.1 \%$ & $-3.5 \%$ \\
\hline & Max & $1.6 \%$ & $41.9 \%$ & $86.5 \%$ & $34.0 \%$ \\
\hline \multirow[t]{3}{*}{ QU } & Min & $-1.6 \%$ & $-16.9 \%$ & $-399.1 \%$ & $0.3 \%$ \\
\hline & Mean & $0.2 \%$ & $3.7 \%$ & $-44.8 \%$ & $9.0 \%$ \\
\hline & Max & $2.8 \%$ & $29.2 \%$ & $219.0 \%$ & $70.2 \%$ \\
\hline \multirow[t]{3}{*}{ ON } & Min & $-2.0 \%$ & $-7.8 \%$ & $-200.3 \%$ & $-23.3 \%$ \\
\hline & Mean & $0.3 \%$ & $6.8 \%$ & $34.2 \%$ & $0.3 \%$ \\
\hline & Max & $6.7 \%$ & $30.6 \%$ & $50.3 \%$ & $7.7 \%$ \\
\hline \multirow[t]{3}{*}{ MN } & Min & $-3.2 \%$ & $-15.4 \%$ & $-794.4 \%$ & $-27.6 \%$ \\
\hline & Mean & $1.7 \%$ & $3.3 \%$ & $0.9 \%$ & $-6.0 \%$ \\
\hline & Max & $12.2 \%$ & $30.5 \%$ & $166.3 \%$ & $64.6 \%$ \\
\hline \multirow[t]{3}{*}{ SK } & Min & $-3.1 \%$ & $-28.2 \%$ & $-504.5 \%$ & $-19.7 \%$ \\
\hline & Mean & $3.5 \%$ & $0.1 \%$ & $31.0 \%$ & $13.2 \%$ \\
\hline & Max & $7.4 \%$ & $44.5 \%$ & $696.4 \%$ & $41.2 \%$ \\
\hline \multirow[t]{3}{*}{$A B$} & Min & $-1.6 \%$ & $-18.4 \%$ & $-85.9 \%$ & $-34.5 \%$ \\
\hline & Mean & $3.4 \%$ & $2.6 \%$ & $20.1 \%$ & $0.9 \%$ \\
\hline & Max & $5.6 \%$ & $33.0 \%$ & $223.5 \%$ & $4.9 \%$ \\
\hline \multirow[t]{2}{*}{ BC } & Min & $-1.7 \%$ & $-14.1 \%$ & $-330.0 \%$ & $-19.0 \%$ \\
\hline & Mean & $2.4 \%$ & $3.6 \%$ & $-12.1 \%$ & $-4.1 \%$ \\
\hline
\end{tabular}

The mean is the average annual rate of growth over the period 2001 to 2008. Max and Min identify the maximum and minimum annual rates of growth over the period. - indicates the rate of growth was measured to and from a base of zero.

\section{DISCUSSION AND CONCLUSION}

The goal of this paper was to examine the role of government financing in determining levels of provincial government age-adjusted spending on health care. It provides an empirical response to Herb Emery's comment that "(S)urprisingly little attention has been paid to how we pay for health care affects how much we spend on health care." 28 Emery examined the issue

28 J.C.H. Emery, "Understanding the Political Economy of the Evolution and Future of Single-Payer Public Health Insurance in Canada," SPP Briefing Papers, The School of Public Policy, Volume 3, Issue 2, February 2010. 
in the context of a theoretical model of how individuals respond to the manner in which they pay for publicly provided health care. Here I examine data describing provincial health-care spending and methods of finance from the past 28 years to investigate the issue empirically. ${ }^{29}$

I find confirmation of hypotheses that political economists have long suggested influence spending decisions. I show, for example, the existence of a so-called flypaper effect that is suggestive that government spending responds more strongly to an extra dollar of income received by way of intergovernmental transfers than it does to an extra dollar of income received from voters; evidence that suggests governments find it easier to expand spending when receiving a transfer from another government than when receiving tax dollars from voters. I also found evidence that revenue gained from borrowing is more conducive to spending than revenue gained from current taxation; a $\$ 1$ increase in borrowing prompts three times the increase in health spending as does an equivalent increase in taxpayer incomes. Finally, a dollar of revenue realized as a return on investment was found to prompt twice as much additional health spending as an extra dollar of taxpayer income.

All of these responses suggest that governments judge that revenue received from taxpayers in other jurisdictions (by way of transfers), revenue received from future taxpayers (by way of borrowing) and revenue received from taxing non-voters (by way of investment income) lowers the cost to them of additional health-care spending. These empirical results are consistent with the idea that financing spending with intergovernmental grants, borrowing and access to investment income creates in the minds of voters a fiscal illusion that additional health-care spending is less costly than is actually the case. It is results like these that are behind the recommendations of a recent IMF study ${ }^{30}$ that sub-national governments be made to face a "tighter" or "harder" budget constraint - one that demands greater reliance on ownsource taxation as opposed to borrowing or intergovernmental transfers - as a way of controlling the growth of health-care expenditures.

The fact that during the past 25 years provincial governments have at times relied heavily on borrowing to finance expenditures, and have continually demanded growth in federal transfers to finance health spending suggests that for much of this time Canadians have not understood the full cost of publicly funded health care. Our calculations show, for example, that over the period 2001-2008, provincial governments spent $\$ 6.75$ billion more on health care than they would have had taxpayers been aware of the true cost of health-care spending promises.

29 The empirical approach taken in this paper is to examine the potential influences of modes of finance on the perceptions of the median voter regarding the true cost of health care. I have not looked at the question of how the preferences of the median voter might differ from those of voters elsewhere in the income distribution. Emery emphasizes that income distribution is important because those with high incomes pay much more for publicly financed health care than those with low-incomes even though all receive the same coverage. There is, then, a potential for a political crisis as the costs of publicly financed health care increase. Carsten Jensen makes a similar point and suggests that this creates a unique challenge to right-leaning governments hoping to balance the interests of the median voter with those who might comprise their natural constituency at the higher end of the income distribution. See "Marketization via Compensation: Health Care and the Politics of the Right in Advanced Industrialized Nations," British Journal of Political Science, Volume 41, Issue 4, pp. 907-926, October 2011.

${ }^{30}$ See Ernesto Crivelli, Adam Leive and Thomas Stratmann, "Subnational Health Spending and Soft Budget Constraints in OECD Countries," IMF Working Paper, June 2010. 
Spread over eight years, $\$ 6.75$ billion is not a huge number when compared to the total amount provincial governments spent on health over this period ( $\$ 795$ billion). On an annual basis the increased spending amounts to only about one percent of provincial health-care spending, depending on the province. However, these numbers are only small in comparison to the vast amount provincial governments spend on health care. In Alberta in fiscal year 2010/11, one percent of the annual health care budget ( $\$ 150$ million), if redirected to other programs, would have been sufficient to increase spending on all of Homeless Support, Early Intervention Services for Children and Youth, Prevention of Family Violence, and Family Support for Children with Disabilities by over forty percent. In Ontario, one percent of that province's health budget ( $\$ 448$ million) would have been sufficient to increase the budget of Children and Youth Services by over 10 percent, or it could have been used to increase the Ontario Child Benefit by nearly 50 percent. Recent research suggests that investments such as these in early childhood interventions offer a high rate of return, a rate of return measured in terms of economic outcomes later in life. ${ }^{31}$ If marginal spending in areas such as these has a greater impact on population health than marginal spending in the health-care system, then how we are choosing to finance health care is contributing to worse health outcomes than otherwise. ${ }^{32}$ The opportunity cost of the extra spending on health care above what taxpayers may have approved had they paid its full cost is therefore considerable.

It is also fair to say, however, that these dollar amounts mean it is inappropriate to suggest that eliminating federal transfers and having provincial governments replace the lost revenue with higher provincial taxes is a panacea for controlling the growth in health-care spending. It would, however, be a step in the right direction. Instead of this, the federal government has announced the renewal of its commitment to continue to grow federal health transfers at six percent annually, ${ }^{33}$ a rate above inflation and population growth. This means a continuation of a mode of funding that results in additional health spending five times greater than what would be the case had provincial government instead been required to raise those funds by taxing provincial taxpayers.

As well as causing health spending to be higher than otherwise, relying on sources of revenue other than provincial taxation makes health-care spending more volatile than it would be otherwise. Thus the large cuts to federal transfers in the mid 1990s contributed to a significant decline in provincial health spending. Provincial efforts at deficit reduction, occurring at the same time as the cuts to federal transfers, also contributed to health spending cuts. Looking ahead, the potential combination of a recession and demands for deficit reduction exposes health-care spending to potential cuts to federal transfers and so another round of provincial efforts to reduce deficits.

31 Eric Knudsen, James Heckman, Judy Cameron and Jack Shonkoff, "Economic, Neurobiological, and Behavioral Perspectives on Building America's Future Workforce," Proceedings of the National Academy of Sciences, Volume 103 , no. $27,2006$.

${ }^{32}$ For discussion on how investments in income security, literacy, children's services and similar programs can reduce direct health-care costs, see Social Determinants of Health: Canadian Perspectives, Edited by Dennis Raphael, 2nd Edition, 2009, Canadian Scholars' Press, Toronto. For a systematic review of research in this area see Sarah Brennenstuhl, Amélie Quesnel-Vallée and Peggy McDonough, "Welfare Regimes, Population Health and Health Inequalities: A Research Synthesis," Journal of Epidemiology and Community Health, Vol. 66, 2012.

33 The Canada Health Transfer (CHT) is to grow at six percent annually until 2016/17, after which it is to grow by an amount equal to a three-year moving average of nominal GDP growth with a minimum three percent rate of growth. 
My calculations, which suggest that voter-taxpayers would have demanded their provincial governments spend $\$ 6.75$ billion less on health care had they been required to pay for it out of taxation, do not say anything about whether this has resulted in the publicly financed healthcare system providing better or worse health outcomes. The potential effect is ambiguous. ${ }^{34}$ On the one hand, a harder budget constraint may cause sub-national governments to avoid socially desirable investments in health care if they cannot otherwise raise revenues to replace those lost by cuts to intergovernmental transfers or borrowing restrictions. On the other hand, a harder budget constraint imposes greater accountability on sub-national governments, because spending is financed from taxes paid by the current generation of provincial taxpayers as opposed to future generations of provincial taxpayers or taxpayers in other provinces. The suggestion is that if consumers of health care are made fully aware of the costs of the health care, they are more likely to play the traditional role of consumers in the economy; that of guarding against waste and inefficiency.

Efforts to investigate this question are fairly recent and the number of studies therefore relatively few. In one recent examination of the question using Italian data, Massimiliano Piacenza and Gilberto Turati ${ }^{35}$ show that efforts to tighten sub-national government budget constraints, while having what they identify as a "remarkable" influence on health spending, did not significantly influence citizen's health outcomes. More research into this question would certainly be welcomed. In particular, it would be useful to learn what areas of healthcare spending are most affected by a tightening of budgets; health services directly impacting patient care or areas of spending less likely to influence health outcomes.

An obvious way of addressing the concern that a hardening of provincial budget constraints might discourage provincial governments from welfare-enhancing health-care expenditures is to ensure they have access to adequate own-source revenues. If, in an effort at cost control, the federal government reduced transfers and also vacated tax room for provincial governments to fill, then it would be repeating an earlier and successful policy to increase provincial accountability for their health-care spending decisions. Eugene Vayda and Raisa Deber ${ }^{36}$ note that when it introduced a cut to federal health transfers in 1977, the federal government compensated provinces with a cut to personal and corporate tax rates intended to create room for the provinces to increase their own tax rates and so fund their own spending programs. The provinces did fill that vacated tax room and so took greater control of health-care financing. A similar suggestion for cutting federal transfers in exchange for a transfer of tax room has been made by Michael Smart, ${ }^{37}$ who notes it would put an end to the fiscal illusion on the part of provincial premiers that more federal transfers can be had without increasing the tax burden on their own citizens.

\footnotetext{
33 The Canada Health Transfer (CHT) is to grow at six percent annually until 2016/17, after which it is to grow by an amount equal to a three-year moving average of nominal GDP growth with a minimum three percent rate of growth.

34 See Martin Besfamille and Ben Lockwood ("Bailouts in Federations: Is a Hard Budget Constraint Always Best?" International Economics Review, Volume 49, No. 2, 2008) for a discussion of this issue in the context of a theoretical model.

35 “Does Fiscal Discipline towards Sub-National Governments Affect Citizens' Well-Being? Evidence on Health," Working Paper No. 12, Department of Economics and Public Finance, Universita Deglistudi Di Torino, April 2010.

36 "The Canadian Health Care System: A Developmental Overview," in C. David Naylor (editor), Canadian Health Care and the State: A Century of Evolution (Montreal and Kingston: McGill-Queen's University Press, 1992.

37 "Federal Transfers: Principles, Practice, and Prospects," C.D. Howe Institute Working Paper, September 2005.
} 
Publicly funded health care is not free. It is expensive. Canadians have not been fully aware of how expensive it is because the many ways it is financed make it difficult for voters to calculate its true cost. The true cost of health care can be and should be made more transparent to voters so that they can more effectively guard against inefficiency and waste, and in so doing contribute to the establishment of a more efficient and effective public health-care system.

\section{About the Author}

Ronald Kneebone is a Professor of Economics and Director of Economic \& Social Policy in The School of Public Policy, both at the University of Calgary. His published research has dealt with issues pertaining to the political economy of government deficit and debt reduction, the history of government fiscal and monetary relations in Canada and the characteristics of Canadian federal, provincial and municipal fiscal policy choices. More recently, his research has examined issues pertaining to the problem of homelessness and income support for persons with disabilities. 


\section{ABOUT THIS PUBLICATION}

The School of Public Policy Research Papers provide in-depth, evidence-based assessments and recommendations on a range of public policy issues. Research Papers are put through a stringent peer review process prior to being made available to academics, policy makers, the media and the public at large. Views expressed in The School of Public Policy Research Papers are the opinions of the author(s) and do not necessarily represent the view of The School of Public Policy.

\section{OUR MANDATE}

The University of Calgary is home to scholars in 16 faculties (offering more than 80 academic programs) and 36 Research Institutes and Centres including The School of Public Policy. Under the direction of Jack Mintz, Palmer Chair in Public Policy, and supported by more than 100 academics and researchers, the work of The School of Public Policy and its students contributes to a more meaningful and informed public debate on fiscal, social, energy, environmental and international issues to improve Canada's and Alberta's economic and social performance.

The School of Public Policy achieves its objectives through fostering ongoing partnerships with federal, provincial, state and municipal governments, industry associations, NGOs, and leading academic institutions internationally. Foreign Investment Advisory Committee of the World Bank, International Monetary Fund, Finance Canada, Department of Foreign Affairs and International Trade Canada, and Government of Alberta, are just some of the partners already engaged with the School's activities.

For those in government, The School of Public Policy helps to build capacity and assists in the training of public servants through degree and non-degree programs that are critical for an effective public service in Canada. For those outside of the public sector, its programs enhance the effectiveness of public policy, providing a better understanding of the objectives and limitations faced by governments in the application of legislation.

\section{DISTRIBUTION}

Our publications are available online at www.policyschool.ca.

\section{DISCLAIMER}

The opinions expressed in these publications are the authors' alone and therefore do not necessarily reflect the opinions of the supporters, staff, or boards of The School of Public Policy.

\section{COPYRIGHT}

Copyright (C) 2012 by The School of Public Policy.

All rights reserved. No part of this publication may be reproduced in any manner whatsoever without written permission except in the case of brief passages quoted in critical articles and reviews.

\section{ISSN}

1919-112x SPP Research Papers (Print) 1919-1138 SPP Research Papers (Online)

\section{DATE OF ISSUE}

June 2012

\section{MEDIA INQUIRIES AND INFORMATION}

For media inquiries, please contact Morten Paulsen at 403-453-0062.

Our web site, www.policyschool.ca, contains more information about The School's events, publications, and staff.

\section{DEVELOPMENT}

For information about contributing to The School of Public Policy, please contact Courtney Murphy by telephone at 403-210-7201 or by e-mail at cmurphy@ucalgary.ca.

\section{EDITOR}

Timothy Giannuzzi 


\title{
RECENT PUBLICATIONS BY THE SCHOOL OF PUBLIC POLICY
}

\author{
A WHITE PAPER* ON REFORMING CANADA'S TRANSPORTATION POLICIES FOR THE 21ST CENTURY \\ http:/ / policyschool.ucalgary.ca/?q=content/ white-paper-reforming-canadas-transportation-policies-21s- \\ century.pdf \\ Brian Flemming | June 2012
}

PREVENTING DOMESTIC VIOLENCE IN ALBERTA: A COST SAVINGS PERSPECIVE

http:/ / policyschool.ucalgary.ca/ ?q=content/ preventing-domestic-violence-alberta-cost-savings-

perspective.pdf

Lana Wells, Casey Boodt and Herb Emery | June 2012

\section{NEGOTIATED SETTLEMENTS: LONG-TERM PROFITS AND COSTS}

http:// policyschool.ucalgary.ca/?q=content/ negotiated-settlements-long-term-profits-and-costs.pdf G Kent Fellows | May 2012

\section{REFORMING THE TAX MIX IN CANADA}

http:// policyschool.ucalgary.ca/?q=content/reforming-tax-mix-canada.pdf

Bev Dahlby | April 2012

TAXING CONSUMPTION OR INCOME: DU PAREIL AU MÊME?

http:/ / policyschool.ucalgary.ca/sites/default/ files/research/cnossen-taxing-consumption.pdf Sijbren Cnossen | April 2012

THE GST/HST: CREATING AN INTEGRATED SALES TAX IN A FEDERAL COUNTRY

http:// policyschool.ucalgary.ca/ sites/default/files/research/bird-gst-hst.pdf Richard M. Bird | April 2012

A PROPOSAL TO CREATE A PAN-CANADIAN ENERGY INFORMATION ORGANIZATION (CEIO) http:/ / policyschool.ucalgary.ca/ sites/default/files/research/m-moore-pancanadian.pdf Michal C. Moore | April 2012

ASSISTED REPRODUCTION POLICY IN FEDERAL STATES: WHAT CANADA SHOULD LEARN FROM AUSTRALIA http:/ / policyschool.ucalgary.ca/ sites/default/files/research/dave-snow-art-final.pdf Dave Snow and Rainer Knopff | April 2012

THE ROLE OF CROWN CORPORATIONS IN THE CANADIAN ECONOMY - AN ANALYTICAL FRAMEWORK http:/ / policyschool.ucalgary.ca/sites/default/files/research/ privatization-crown-corp.pdf Edward M. Iacobucci and Michael J. Trebilcock | March 2012

TANTALUS UNBOUND: GOVERNMENT POLICY AND INNOVATION IN CANADA

http:// policyschool.ucalgary.ca/sites/default/files/research/macintosh-final.pdf Jeffrey G. MacIntosh | March 2012

IMPLICATIONS OF THE RECOMMENDATIONS OF THE EXPERT PANEL ON FEDERAL SUPPORT TO RESEARCH AND DEVELOPMENT

http:// policyschool.ucalgary.ca/sites/default/files/research/mintzmanning-fed-supp-1.pdf

Preston Manning and Jack Mintz | March 2012

SMART ENVIRONMENTAL POLICY WITH FULL-COST PRICING

http:/ / policyschool.ucalgary.ca/sites/default/files/research/olewiler-online.pdf

Nancy Olewiler | March 2012 